\section{Court judgement opens door for study of ancient skeleton}

\section{Rex Dalton, San Diego}

In a major victory for US archaeologists and anthropologists, a court has ruled that they can go ahead and examine Kennewick Man, a 9,200-year-old skeleton found six years ago in a river-bed in Washington state.

A US district-court judge in Portland, Oregon, ruled on 30 August that the Department of the Interior had been unjustified in its September 2000 decision to hand the skeleton to five Native American tribes, who did not want any research to be done on it.

A group of scientists first filed a lawsuit in 1996 to demand the right to study the skeleton, which could provide significant information about early human migration in the Americas. One of them, Robson Bonnichsen, an anthropologist at Texas A\&M University in College Station, said: "The decision is terrific, it will benefit everyone."

A spokeswoman for the Department of Justice said that the government wouldn't comment until it had reviewed the decision. But spokesmen for the Native American tribes expressed disappointment, saying that the court had prevented them from exercising their rights under the Native American Graves Protection and Repatriation Act.

The ruling is likely to have implications for the study of early human migration in the United States as it will make it harder for Native Americans to use the act to prevent the study of other specimens. One example is a skull unearthed in 1999 in a bog near Houston, Texas. Radio-carbon tests suggest that it is about 11,000 years old. Such specimens are now more likely to be fully studied, although Native American tribes will still be able to claim the remains and rebury them afterwards.

http://friendsofpast.org

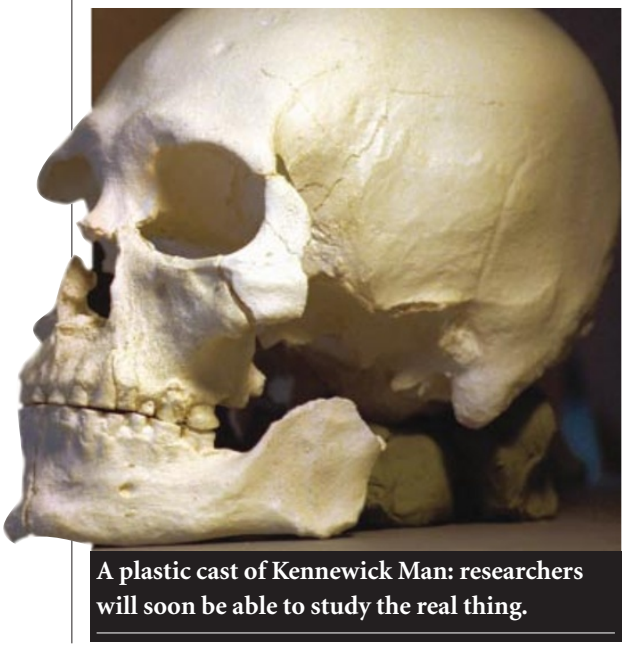

\title{
Diabetes trial stirs debate on safety of xenotransplants
}

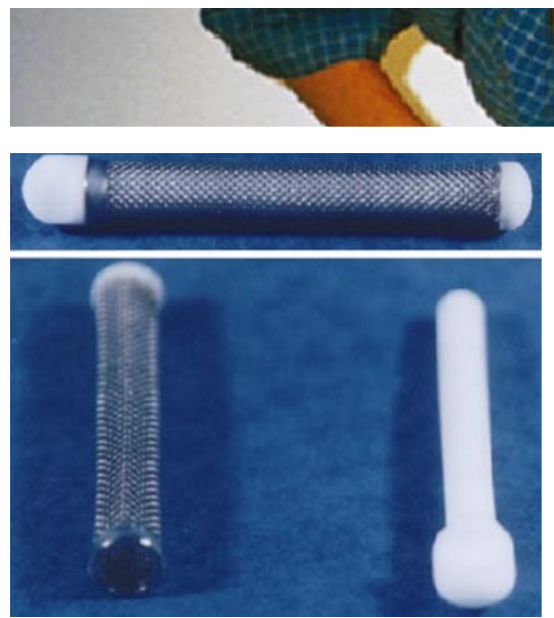

\section{Erika Check, Washington}

The use of pig cells to treat Mexican patients with diabetes has sparked a fresh round of debate on the ethical and social issues surrounding xenotransplantation.

In the study, Rafael Valdés of the Children's Hospital of Mexico in Mexico City implanted pig cells into 12 adolescents in an effort to cure their diabetes. His approach — which used specialized cells to protect the transplants from the host patients' immune systems has never been tried before in humans. On 27 August, Valdés told the XIX International Congress of the Transplantation Society in Miami, Florida, that his preliminary results are promising, although other scientists are reserving their judgement.

Valdés' approach has not been properly tested in animals, critics say. They want to know if any benefits from the treatment outweigh the risk of exposing patients - and the rest of the population - to new pathogens that might be carried by the pig cells.

But Valdés says that the Mexican government approved his trial. His critics point out, however, that Mexico has no published guidelines on clinical trials in xenotransplantation.

"I don't think anyone is trying to say to people in other countries, 'We want to tell you what to do'," says David Cooper, an immunologist at Massachusetts General Hospital and past president of the International Xenotransplantation Association. Nonetheless, Cooper is worried by the theoretical potential of xenotransplantation to transfer infection into the human population. $\mathrm{He}$ thinks that any proposed approach should at least be proved to work in non-human primates before it is tried out in people.

Valdés gave his trial participants implants of pancreatic cells from pigs, which produce
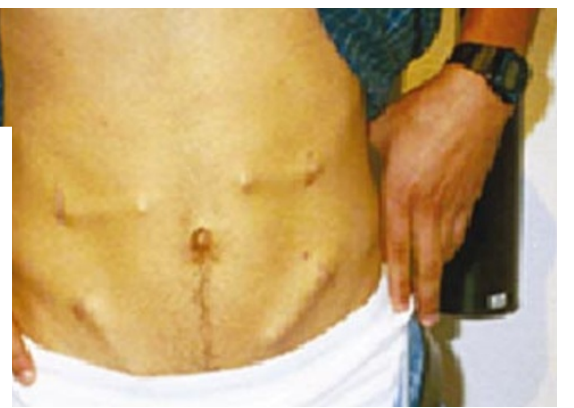

Using implants (inset), Mexican scientists have given pig-cell transplants to diabetes patients .

insulin, the essential hormone that is deficient in the 150 million diabetics worldwide. To prevent the transplants from being rejected, Valdés also implanted cells from the pigs' testicles, known as Sertoli cells. These cells have been shown to protect transplanted tissues from a recipient's immune system in some animal models.

Valdés said in Miami that the implants have allowed one child in the trial to stop taking insulin injections completely, and five others are taking less insulin than before. The result was achieved without using immunosuppressive drugs, which have harsh side effects but are normally given to transplant recipients for the rest of their lives. If confirmed, these results would be unprecedented, researchers say - nobody has ever weaned a diabetic patient off insulin injections without using lifelong immunosuppression.

The results have prompted calls from some researchers for Valdés to study his technique in non-human primates as soon as possible, but Valdés says that he plans to go straight ahead with a trial in 24 more humans.

Critics are challenging Valdés over what steps he is taking to stop his patients contracting infections from pigs. He says he is following US Food and Drug Administration (FDA) guidelines for xenotransplantation trials. Scientists from developing countries often use these guidelines even though the FDA has no authority outside the United States.

But other researchers say that the FDA would not have approved Valdés' trial for several reasons, including the lack of preclinical studies and the fact that his work was in patients too young to give proper informed consent.

"If you have a technique like this that you wouldn't do in Britain or the United States, but it works, where does that leave your ethics?" asks Alan Colman of Singapore-based company ES Cell International. "There is no moral high ground here - but I do think this experiment went beyond the pale." 